International Journal of Social Sciences and Humanities
Available online at http://sciencescholar.us/journal/index.php/ijssh
Vol. 2 No. 2, August 2018, pages: $226 \sim 242$
e-ISSN: 2550-7001, p-ISSN: 2550-701X
https://doi.org/10.29332/ijssh.v2n2.168

\title{
Transformation of Masatia Tradition towards Hindu Religion in Bali
}

I Nyoman Suada a ${ }^{\text {, I Putu Gelgel }}{ }^{\mathrm{b}}$

Article history: Received 10 April 2018, Accepted in revised form 25 July 2018, Approved 15 August 2018, Available online 17 August 2018

Correspondence Author

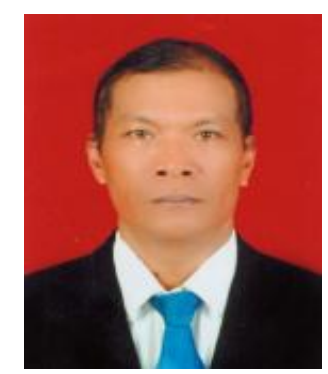

Keywords

Bali;

Hindu religion;

Kingdom;

Masatia tradition;

Transformation;

\section{Abstract}

The study of masatia tradition transformation towards Hindu in Bali was a study of religion and culture using qualitative research with religious and cultural approaches. The study emphasized on the more background, process, and impact of the transformation of masatia traditional in the pitra yadnya ceremony in Bali. The phenomena raised and discussed lead to the transition of tradition, the customary law of the kingdom and its impact on the society and responses from the Dutch colonial government particularly in Bali. The masatia transformation was occurred in Bali for the 1908-2014 period due to the transition of the colonial rule which in this case was Dutch colonialist. The masatia tradition has been known since 1597 to 1843 and was formally abolished in 1908. The masatia tradition was banned in Bali by the Dutch written agreement with the king of Bali. Although it has been banned, there was only a government to practice masatia in secret until the 1920s. The process of transforming the masatia tradition for each castle in Bali takes place slowly. For the Buleleng castles since 1849 might be stated that there was no more masatia, then followed in the kingdom of Jembrana, Badung, Tabanan, Bangli, Karangasem, Gianyar, and finally in Klungkung. The process of substituting masatia of the fire occurred the transition process. But, in the end, as a successor was approved by the kings in Bali substituted for masatia rambut. The masatia rambut was used as a substitute due to Hindu community in Bali especially, the hair was considered the most sacred. The hair that was located on the head and as the center was the crown. As a result of the masatia transformation involved the term of tatwa, deeds, ceremonies, and upakara (offering tools).
\end{abstract}

e-ISSN : 2550-7001, p-ISSN : 2550-701X ๑ Copyright 2018. The Author. SS Journals Published by Universidad Técnica de Manabí. This is an open-access article under the CC BY-SA 4.0 license (https://creativecommons.org/licenses/by-sa/4.0/) All rights reserved.

a University of Hindu Indonesia (UNHI), Indonesia

b University of Hindu Indonesia (UNHI), Indonesia 


\section{Contents}

Abstract

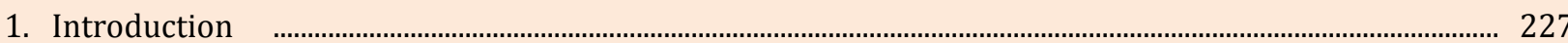

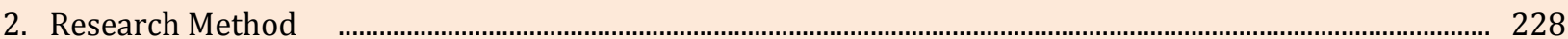

2.1 Concept of masatia tradition transformation ....................................................................................................... 229

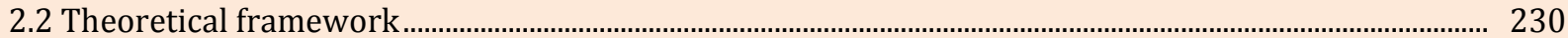

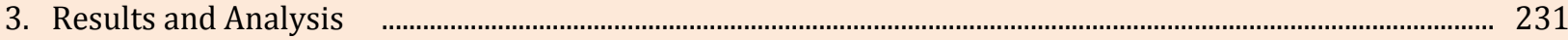

3.1 Belief and development of Hindu religion ........................................................................................................... 231

3.2 Process of masatia transformation .......................................................................................................................... 233

3.3 Impact of masatia tradition transformation ........................................................................................................ 233

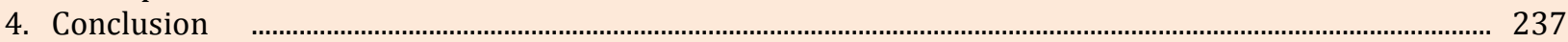

Conflict of interest statement and funding sources......................................................................................... 237

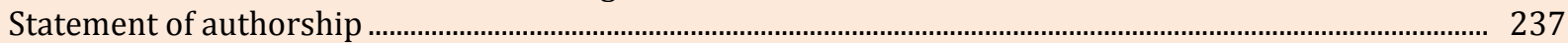

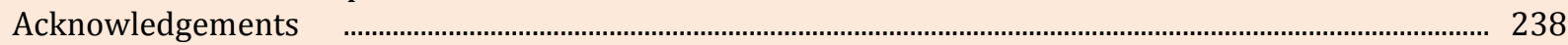

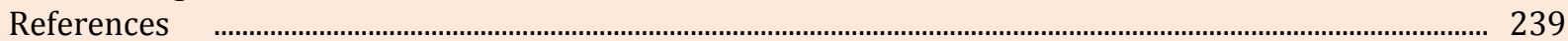

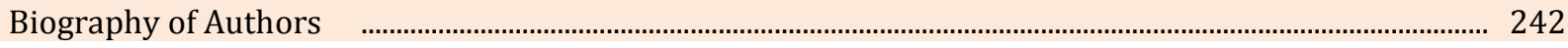

\section{Introduction}

The masatia tradition in Bali could not be separated from India's masatia tradition. This tradition was believed to be the custom of the masatia from India who embraced Hinduism. India's masatia tradition was very closely related to the legend of Dewi Sati, as well as known as Dakshayani (Devanagari: Dakshayani). Dakshayani was the first consort of Shiva, Parwati secondly, the reincarnation of Sati herself. This legend told that Sati was born as the daughter of Daksa Prajapati and his wife was Prasuti. Daksa was a son of Brahma and the great king. As Daksha's daughter, she was also known as Dakshayani. She was also called Sati. Sati logically was the grandson of Brahma.

The existence of the masatia tradition already in Bali has been long based on the sources found. The masatia tradition was referred to from foreign news. In 1633 a Dutchman named Jan Oosterwijk noted the existence of the masatia ceremony in Bali. In the palebon (cremation ceremony) for two of king's son were adhered by 42 women for a son of the king and 34 men for the other one. There were stabbed and burned. The woman by the higher degree immediately threw herself into the embers of her husband's place at pengabenan (the place for the wherein dead body was burned). It was not called the name of the king and his kingdom. Observing the number of the year, it could be stated happened in the Gelgel era (Creese, 2012: 262-263). Based on the analysis of the researcher, this period was during the reign of Dalem Di Made (1630-1651) who lead in Gelgel, the son of Dalem Sagening (1580-1630). Kusuma (2010: 54), stated that Babad Mengwi, V.E. Korn collection, Padanda Wanasara's wife conducted masatia after her husband was killed by I Gusti Agung Putu in Keramas. This occurred due to I Gusti Agung Anom in Mengwi gave his brother to Padanda Wanasara as a wife (Korn, 1940: 13-14).

The masatia was a tradition that has been long held in Bali, wherein the king's concubine throws herself in the flames of life state. The masatia was thought mastering taken place in Bali since the Gelgel era. When the kingdoms emerged in Bali, since the reign of Dewa Agung Jambe who became the first king in Klungkung in 1686, the masatia was estimated to be increasingly lively, especially in the XIX centuries and at the beginning of the XX centuries. The masatia was one of the things that can increase the king's authority. The relationship by the Netherlands, the final agreement the king's rights were limited to entering into an agreement to abolish the masatia in the XIX centuries. The number of kingdoms continued to hold masatia tradition included Tabanan kingdom until the beginning of the twentieth centuries (the 1920s). It was explicitly stated that during the masatia implementation followed by the musical instruments e.g., gambelan (Balinese instruments music) and others (Delgado, et. al.; 2013). The study was formulated into the three problems that would be discussed. Those were (1) why the masatia tradition transformation occurred? (2) how the process of masatia tradition transformation occurred? (3) what the impact of the masatia tradition transformation in Hindu religion in Bali?

Suada, I. N., \& Gelgel, I. P. (2018). Transformation of masatia tradition towards Hindu religion in Bali. International Journal of Social Sciences and Humanities, 2(2), 226-242. https://doi.org/10.29332/ijssh.v2n2.168 


\section{Research Method}

The study of masatia tradition transformation towards Hindu in Bali was a study of religion and culture using qualitative types with religious and cultural approaches. The qualitative research was a research procedure that interpreted the data descriptively, paraphrase, oral or written from observed the community behavior. The study emphasized on the more background, process, and impact of the transformation of masatia traditional in the pitra yadnya ceremony in Bali. The phenomena raised and discussed lead to the transition of tradition, the customary law of the kingdom and its impact on the society and responses from the Dutch colonial government particularly in Bali. Due to the research used a qualitative type, the measurement was not a principle, because it would not produce generalizations. Related to the research type, Hendra (2015), argued that qualitative research actually emphasizes quality observation. Likewise, the study of the transformation of the masatia tradition was focused on the quality of "phenomena" or events, not on certain quantum aspects, which have an impact on the development of the society and invaders in the certain period (Arniati; 2018, Suarda, et al.; 2018, Indiani, et al.; 2018).

\section{Research location}

The research location generally was in Bali. It was emphasized on the former castle in Bali. The former castle was known in the nineteenth century were ten kingdoms survived currently. The ten kingdoms included kingdom of Buleleng, Jembrana, Tabanan, Badung, Gianyar, Bangli, Klungkung, Karangasem, Payangan, and Mengwi. The Mengwi kingdom finally collapsed and the area mostly fell into the Badung kingdom. Previously, the Payangan kingdom had been attacked and under Klungkung supervision. But, the territory fell finally into the hands of the kingdom of Gianyar. The masatia was traditionalized or cultivated in a number of kingdoms in Bali was very unique and contains very "horror" characteristics. Due to the humans were burned or burn themselves alive. The culture or tradition has a profound impact on the development of the society and the same time in period for each kingdom carries out masatia greatly influenced the Dutch who want to rule politically in Bali.

\section{Types and data sources}

Regarding history, the effort of the person who wants to compile history could choose a subject and gather information about the subject (lately called heuristics). Related to the documents, it must be related to the government library. If the document was private, then it must be searched like in Puri. The data for the sample was in the document. Writing and oral sources were twofold, i.e., primary sources were testimonies from a witness of the head or witnesses self with other senses or other mechanical devices (also called witnesses). The secondary sources were testimonies from anyone who was not involved directly those who were not present at the story of the incident occurred if the photocopies can be originally created (Gottschalk, 1975: 33-34). The technique of collecting the data in the present study used i.e., observation, interview, and document studies.

\section{Research instruments}

As it was known as a qualitative research, as the main instrument was the researcher himself (key instrument), the aim of getting better results, careful, complete, and systematic. Then, the interview guidelines were used in the form of questions submitted to the informants. Regarding stationery was a tool to record the answers given. The stationery and use cellphone cameras to capture images and the same time, they were used for recording. To avoid undesirable things like sudden damage to recording devices and image obedience, researchers used a spare cell phone. Using instruments the research was able to reveal the data needed, especially regarding the transformation of the masatia tradition in Hindu religious life in Bali. It was then transformed into masatia rambut (magundul) and also in other forms that lasted until the present era. 


\section{Technique of data analysis}

This study used a qualitative descriptive analysis. The data analysis was a very important stage and carried out at utilizing several types of data obtained from primary and secondary data. The results of library research, interviews, observation results, recording results, recordings, documentation results, and others.

\subsection{Concept of masatia tradition transformation}

The lexicon 'transformation' comes from the word transfor defined to divert or replace or find a replacement solution. In the KBBI (2005) the lexicon defined a change or to change. Related to the growth and roll-up of the culture are historical, the civilization emerges when human beings experienced difficult aspects that challenged it to produce unexpected creative activities in the challenge end response. The existence of challenges arose from civilization (Sutrisno et. al.; 2005), the lexicon tradition i.e., the habits that occurred in the society that a tradition developed has been long thickened. It, therefore, was seen by the society as a sacred. The tradition was perhaps, if the interpretation, it generally was a habit that has long settled in the society. It occurred in the society has been standardized of supporting community. The habit for each village in Bali was different. It could be stated that traditional villages in Bali to be 'countries' which mastering their own autonomy. It was found in desa adat pakraman (traditional villages in Bali only) about 1500, the more certainly in the $19^{\text {th }}$ century. The currently occurred many of desa adat (banjar adat) have emerged related to donation from the government (Geertz, 2000: 86-87). Regarding the change, continuity in the society was often maintained by the social traditions handed down in subsequent generations. The lexicon tradition defined customs, beliefs, habits, teachings, passed down from the ancestors (Poerwadarminta, 2011: 1293). In English, the tradition was called tradition which was defined as 'tradition' (Echols et al., 1984: 599).

According to Subramanian (2005), satya means true, real, original. The lexicon thus means doing an act by throwing the self into a fire bed. This was conducted to show the loyalty to the husband. In this case, the one who commits the actions of the masatia was the king's wife. It, therefore, can be stated that masatia was a tradition of suicide takes place in Bali by throwing itself into a fire bed to show loyalty to the husband (the deceased of the king). According to KBBI (2005), masatia comes from the lexicon satya defined (1) rules that are commonly followed, or done since time immemorial; (2) habits; a way that has become usual. It was stated that people in power usually abuse their authority. The lexicon satya was interpreted. There were a number of the lexicon related to satya included: satyadwaya (two truths), satyabrata or satyawrata (faithful to promises), satyabhakti (loyal and devoted, always loyal), satya wecana (right, straight, truth, honest), satyawakya (right, righteous heart), satyawada (right, straight hearted). KBBI (2005), the word faithful means: (1) Stay and be steadfast as in friendship, servitude, marriage etc.; (2). Means obedient, and (3) Holdfast.

One of the Hindu cultural heritages integrated of the tradition was the term of masatia in Bali. According to the KBBI (2005), the lexicon satya means faithful, trustworthy; honest; promise; swear. If it was defined freely, masatia was an act carried out, generally by the king's wife by throwing herself in the fire bed when the king's dead body was being burned. It was to show her loyalty to her husbands. According to Hindu religion, it was a sacred act. The truth based on the philosophy of science, due to the philosophy of truth science was relative, according to each truth. The ban was carried out during the Dutch rule after Bali was completely defeated in 1908.

\footnotetext{
"Arsa Sri nateng Nambangan, amasmi Sri nateng Mengwi, ring setra ngawe kekuwon, akweh nata anyarengin, tan lingen kawiryaneki, satoning subala wibuh, mang keprapta attiwan, binasmis sakwehing mayat, tang satya iku, sampun munggah atotoyan". (Gaguritan Buwana Winasa: 16a-16b). Translation:

"The honour of Badung king was very pleased, then, burned the Mengwi King corpse, made a building in the grave, many kings accompanying, unspeakable that luxury, because of its many people, now come the pengabenan (creamation ceremony), all the dead bodies were burned, the satya women, already up the cleaning place (stage)."
}

What was meant of the king's wives who the stage up and threw themselves into the fire as a loyalty expression? Showing the loyalty to the king particularly was shown in several ways such as falling on the battlefield against the enemy, suicide near the king's dead body, throwing herself into the fire when the king Suada, I. N., \& Gelgel, I. P. (2018). Transformation of masatia tradition towards Hindu religion in Bali. International Journal of Social Sciences and Humanities, 2(2), 226-242. https://doi.org/10.29332/ijssh.v2n2.168 
was burned. This was clearly conducted of the loyal servants of the Badung kingdom against the Dutch in 1906. The king knew that he would definitely lose, the Badung king's dead body had been burned in a laying with a complete ceremony (Geguritan Buwana Winasa: 29b). I Gusti Ngurah Made Agung was Badung King conducted potong gigi (the ceremony of teeth cutting) conducted by Pedanda Taman (Balinese priest).

It was true the statement of Anak Agung Putra Agung, the expander of Puri Agung Karangasem that masatia was not only conducted by throwing herself into the fire, but it could also be in the war, as the war of Puputan Jagaraga, Puputan Badung, Puputan Klungkung, Puputan Margarana (an interviewed to Anak Agung Gde Putra Agung, 12 December 2014). As for the concept of the attainment of the heaven through the war, there are several verses of Bhagawad Gita (1972).

Gaguritan Bhuwana Winasa also mentioned that if she died on the battlefield, she was in the heaven. Their belief in dying of the spiritual war would get a heaven. That was why they have died in the war based on their belief, it was not because of giving up.

Sinom Uwug Payangan (1982), stated that people who die in a war they would get a heaven and there have been previous signs. In the Smrti Ajaran Kebudayaan Hindu Bali book (Medera; 1989), stated that committing a murder (himsa) to humans was only permitted to people whose faults of wrat pati, according to the verdict of the judge, and to the enemy being in a war that kept Dharma-Yudha. Dharma-Yudha means a wet war carried out blatantly, a war of rivalry, both armed. It was not permissible to kill unarmed enemies, who run away from their weapons, who surrender ask to be lived. Due to they were deemed cowardly, surely got the world disgrace when it was still alive and a hell of the death. For a hero or Dharma-Yudha was fulfilled, because if s/he won in the warfare could be praise and respect of the world, the dead time was a heaven (Sugriwa, 1978: 75).

It ought to be emphasized that the masatia tradition transformation for each region has a difference. Thus, it could be stated that the changes habit of suicide by throwing themselves in the flames of fire to show loyalty to the husband. After the Dutch took the power of the king of Bali, they were replaced by masatia rambut (hairs). The masatia rambut as a change for masatia tradition began to be carried out by the king in Bali, after, Bali could be fully controlled by Dutch colonizers. It was known that Bali as a whole could be controlled by the Dutch in 1908. Klungkung was considered as the king of Bali and Lombok. It has lost against the Dutch as well as consider the war in Bali to be finished. Finally, the king of Bali agreed to replace masatia in Gni (fire), i.e., burning the self in a way that was not contrary to humanity, e.g., cutting the hair in bales were exhausted, the Balinese term was called magundul and also as the worship form.

\subsection{Theoretical framework}

The theory was used to analyze the relationship between the one fact and another. The point here was that it could change. Therefore, this was indicated that the theory comes from drawing conclusions that have the potential for error, in contrast to drawing conclusions on proof of theoretical mathematics formulated, developed, and evaluated according to the scientific method. It was also a hypothesis that has been proven true. The humans designed to predict and master certain phenomena. There was a generalization of many observations and stands for a collection of ideas that were coherent and interrelated.

\section{Theory of religion}

Religion was a spirit that occupies the surrounding environment. There was wherein developed giving birth to the gods of natural, and finally became the highest the god of kings natural. There was a belief in the development of the society that there was a belief in God (Koentjaraningrat, 1987: 50). Hindu in Bali believe in God, adores excessively accompanied of the masatia tradition. It was required by the king. Due to the king was considered to be God. This was considered by Westerners to be contrary to humanity. This theory was used to answer the first problem.

\section{Theory of power}

The power has a neutral nature must be seen from its use for the needs of the society. That power exists in every era, simple or traditional or in the modern times. The existence of the power was very dependent on the holder of the power was controlled. In other words between the parties who have the ability to wield influence 
and other parties who accept the influences, willingly or compulsively (power was any ability to influence others (Soekanto, 1987: 241-242). The most appropriate theory used was the theory of (Foucoult; 1980, 1982, 1984). The theory context of the structuralism in France then tried to move to overcome them in poststructuralism. He generally was a poststructuralist, although he developed his own unique theory. The development involved creating a new method that was independent of individuals who highlight discourse practices. His work has a strong influence on the sociology theory currently. His work through structuralism and post-structuralism remain a living charm.

In his work entitled Discipline and Punish, he presented a "correlative history between modern souls and a history of the new power to the judge" the current scientific-legal genealogy that was the basis, justification, and rule for the punitive power. It was the basis for punishment. It was the basis for punishing to expand its influences and become a tool of the power to cover its single wealth. It exceeded the limit. Foucoult (1977/1995) traced the modern criminal system. In the process, it was shown how the knowledge and power were directly related to each other. The power in the prison system, and elsewhere was based and expressed in the form of observation, an assessment that standardizes the investigation. Although the Dutch could defeat Bali, the local structure was still carried out, meant the officials in the structure were still running. This theory was used to answer the second problem.

\section{Theory of social change}

Related to the theory of social change, the theory used was proposed by (Salim, 2014). According to the study, the concept of social change that occurred in Southeast Asia has a sharp difference. It was seen from the changing dynamics of the community. There were five main concepts about the basic theory of the dynamics of the social change in Southeast Asia, including dual society theory, society pluralism theory, the theory of the loosening of community structure, evolution theory and industrialization and modernization theory (Salim, 2014: 132-133). This theory was used to answer the third problem.

\section{Results and Analysis}

\subsection{Belief and development of Hindu religion}

The belief, especially towards the existence of the Almighty God/Ida Sanghyang Widhi Wasa, is very pure on the souls of the Balinese people. The named of Ida Sanghyang Widhi Wasa is closer to Hindu in Bali. The level of Balinese belief comes from Hinduism, belief in the supernatural, human relations to the God, and belief in the attributes to all its manifestations. It cannot be denied of the religion developed at that time in Bali was Hinduism and Buddhism. The Hinduism particularly has developed since Bali Kuna.

The development of Hinduism defined in the Balinese ancient era here was in the period around the $\mathrm{X}$ centuries until Bali was defeated by the Majapahit kingdom in 1343 AD. It was known that governing in Bali in the $10^{\text {th }}$ centuries of the government center in Singamandawa (around between Pejeng-Bedulu) was the king of husband and wife, namely Udayana Warmadewa and Ardanaresuariya Sri Gunapriyadharmapatni (Mahendradatta). Sri Gunapria Dharmapatni was descended from Empu Sendok which sent down the Isana dynasty in East Java. Whereas Udayana Warmadewa descendant in Bali kingdom. Warmadewa dynasty presenced in Bali can be seen from in Blanjong Sanur inscription, in 913 AD.

During Udayana Warmadewa reign with his queen was Sri Dharmapatni came the great spiritual master from East Java. Empu Kuturan mentioned in a number of sources with the Empu Bharadah spiritual empowerment. These two spiritualists lived in the reign of King of Erlangga in Kediri, East Java. After being in Bali, they organized and established dharma and Balinese society. Understanding Tri Murti, which developed first in East Java was established in Bali and since then or after a meeting at the Pura Samuan Tiga Bedulu, Kahyangan Tiga was built as a place of Bahtara "Tri Murti” (Ardana, 1982: 30). Ardana (1982: 30-31) stated that Kahyangan Tiga was the three temples that must exist in each desa adat/pakraman in Bali, namely:

a) Pura Desa/Bale Agung is the place to glorify the Lord of Brahma as creator.

b) Pura Puseh is the place to worship or glorify the Lord of Vishnu as a look after.

Suada, I. N., \& Gelgel, I. P. (2018). Transformation of masatia tradition towards Hindu religion in Bali. International Journal of Social Sciences and Humanities, 2(2), 226-242. https://doi.org/10.29332/ijssh.v2n2.168 
c) Pura Dalem is a place to worship or glorify the Lord of Shiva as the manifestation of Ida Sanghyang Widhi Wasa as a regulator or a melt.

The background of masatia transformation

a) Power

In its relevance to the masatia in Bali, the one in power was very wide. Due to the power of the people can influence the population of its territory. The motto of the king was considered a "descendant of the god" or "the representative of God," it gave a great opportunity to the authorities to do something that was considered the right for him. This was surely very subjective in its truth. But, the atmosphere in his era was difficult for the people to fight, the authority of the authorities was very wide. The king who ruled in a kingdom was considered the command of the God, therefore, the people were afraid of the God.

Related to power, according to Nordholt (2009) stated that Bali was a variety of kingdoms of the each disagree about power and prestige to other and internally these countries constitute the whole of hostile big and small kings. As the system of royal government, it was affirmed that the power of the king, if he wanted to remain lasting, must be truly visible and physically firm. The king will be able to succeed if he was able to demonstrate the hierarchical order and at the same time be able to mobilize the support of the majority of his people on the basis included:

1) Humanity

2) Era development

3) There were fear and self-esteem

4) In order to remain seen as honorable noble

5) Finance ability

6) The existence of the Ngayah and Maturan systems

7) People support

\section{b) Masatia tradition}

Related to the transfer of power for the kings in Bali to the Dutch was colonial government, according to Schulte Nordholt (2002), Bali did not experience enormous historical changes. In the period from 1650-1900, it was stated that important changes had taken place which resulted in very large differences between XIX century Bali and XVIII century Bali. The fall of the power of the kings of southern Bali in the period 1906-1908 brought a series of fundamental changes, the further influenced relations. A very important change among them was included in the framework of a larger Colonial power. Actually, the Dutch have a goal to isolate Bali from the outside world at arguing to preserve the Bali traditionality. As in the concrete, it is stated that Bali has undergone a change, meaning that it was not in accordance with the situation in the past (Nordholt, 2009: 18).

There is currently still any perception that culture or past traditions are better. Bali was experiencing phases in historical development while maintaining Hindu religion in the majority. Since the Bali Kuna (Old Balinese) era namely starting from the reign of King Sri Kesari Warmadewa IX century AD until the collapse of the ancient king of Bali. There was revealed, namely Sri Asta Sura Ratna Bumi Banten in 1343 AD, still maintained Hindu religion. This can be proven by several historical relics such as Pura Penataran Sasih, Pura Tirta Empul, Pura Dalem Balingkang, Pura Pengukur-Ukuran, Goa Gajah, Pura Besakih, and many other temples from the Bali Kuna era. The Hindu religion in Bali has existed since the VIII century based on archaeological evidence, not through intimidation or violence, however, through the trade and government channels.

\section{c) Religious ceremony}

Hindu people in Bali was very full of the religious ceremony system. It was a religious behavior that was carried out in accordance with the standard behavior with sequences cannot be reversed. The ceremony itself was the efforts to prove their belief and at the same time with evidence as well as establish it. The meaning of establishing was to clarify the concepts and formulations about something that was believed. To clarify, it was 
completed by mantras, prayers of praise, actions, bhakti, gestures, and symbols. The purpose of the religious ceremony was to find the relationship between the human and the niskala (unseen world), the interpretation of obedience/discipline to their beliefs hoping to be kept away from havoc, etc. (Pujileksono, 2009: 68-69).

\subsection{Process of masatia transformation}

The transportation process for masatia tradition of Hindu in Bali underwent a change in the Dutch era, i.e., when the Bali was fully politically controlled. The political field was very influential towards tradition. In this case, the Dutch urged the king of Bali was to sign the treaty (pasobaya) of the masatia tradition. In fact, the castles had realized that their rights had been reduced. Due to it seems that the Dutch have been convinced of its strength, if, there was resistance from the king of Bali, it would be opposed by the guns. The Dutch also realized that the masatia tradition was the dignity of each king in Bali, the other customs which could also elevate their respective kingdoms.

The Dutch arrival under the leadership of Cornelis de Houtman in 1597 has not yet been signed for a real political contract against the rulers in Bali. This lasted until the XVIII centuries. After the Dutch felt strong in the middle of the XIX centuries, it was desirable to control Bali politically. Regarding some reports, it seems that the problem of the masatia tradition was one of the parts that the Dutch needed to address. The Dutch would intervene in the traditions of ancient or orthodox traditions and humanitarian contradictions. The king of Bali was approached become a treaty of the abolition of the tradition.

Related to the masatia tradition, the Dutch held agreements with the kings in Bali to abolish the masatia tradition. They did to the Tabanan kingdom a customary abolition of the masatia was held on January $20^{\text {th }}, 1904$ (Arsip Nasional, 1964: 42). To the king of Klungkung, a masatia tradition agreement was held on November 22 nd 1904 (Arsip Nasional, 1964: 42). Due to Klungkung was considered the heir of Majapahit in Bali, the Klungkung kingdom was intended by the Dutch to sign the masatia tradition. At that time, the king of Klungkung kingdom was Dewa Agung Jambe who had the title Dewa Agung Putra IV who had a flexible attitude towards the Dutch (Ardika, 2013: 435). Then proceed to the Badung kingdom which was held on December 22 ${ }^{\text {nd }}, 1904$ (Arsip Nasional, 1964: 42). It was mentioned in the agreement with the king of Badung was clear that the masatia tradition was not permitted by the Dutch, in fact, the husband nyatyan who was burned or whoever was in the Badung kingdom. The agreements to the other kingdoms were essentially the same those held with the Badung kingdom. To the Bangli kingdom, the treaty was abolished on January 19th, 1905 (Arsip Nasional, 1964: 42).

After the Klungkung kingdom defeated by the Dutch, there were still many people who were grudging, therefore, the Dutch continued to conduct strict supervision in the Klungkung area, especially, in the area around the castle. If there was a castle family dies, intensive supervision was carried out. There was no tradition or masatia tradition was carried out by the family or others. A long period from 1908 to 1945, the atmosphere was truly conducive under the Dutch supervision. However, the coordination with the kings in Bali continued to be sought to find alternatives, replace of the masatia tradition. Due to the love of the Klungkung people, spontaneously most of them did the masatia rambut or magundul before the palebon. Looking at the other kingdoms comparisons, such as in the kingdom of Mengwi, Tabanan, Badung, in 1939, had been conducted the masatia rambut or magundul.

\subsection{Impact of masatia tradition transformation}

According to Martono (2014), stated that a change always has negative and positive impacts. This impact could occur directly or indirectly (Martono, 2014: 26). Especially, regarding the social change and cultural change can only be distinguished the social understanding to the culture. The social change was a part of the cultural change. Thus, it can be stated that the cultural change was broader than social change. The social changes and cultural changes that occurred in the society was interrelated. There was no society that has a culture and on the contrary, there was no culture without society (Martono, 2014: 12). If this was a case, the masatia tradition was clearly human. Bali, especially, those were affected of the Hindu influences from India which still maintained the masatia tradition until the XIX centuries and early XX were considered by the Dutch to be very barbaric in contradiction with humanity. The Dutch wanted to abolish and after being abolished by

Suada, I. N., \& Gelgel, I. P. (2018). Transformation of masatia tradition towards Hindu religion in Bali. International Journal of Social Sciences and Humanities, 2(2), 226-242. https://doi.org/10.29332/ijssh.v2n2.168 
the Dutch, the descendants of the king of Bali transformed them into masatia rambut as the form of the worship. Discussing the impact was related to the influence of the masatia tradition transformation for Hindu civilization in Bali particularly. The Balinese culture from time to time continued its experience change, due to the eternal was change. In the scientific context, a culture was actually a special plot of the science of the cultural anthropology. The sociology was also very close to culture, therefore, those who call duumvirate (Purbacaraka, 1982: 165). All impacts can be explored as follow towards:

\section{a) Towards tatwa and susila of Hindu}

Tattwa was the content of sraddha (belief) in Hindu religion. Tatuwek-tatuwek or utterance in Bali, there were so many models like the stories that developed in satua Bali (Balinese stories). The most of the stories consist of learning, karmapala (action vs result) etc. The Hindu currently still strongly believe in the law of karma, but it is not sure about karmapala. For example, that was about the ancient masatia, it was believed that the soul will get a heaven. But, in the end, the masatia tradition was abolished and replaced with masatia rambut that developed currently. According to Hindu, Susila defined the attitude of the behavior. The behavior is meant by the existence of several rules that are used as a basis for everyone in their behavior to be controlled, harmonious, and in accordance with the basic attitude of human beings themselves as individual beings and as social beings. As human beings, the human has different interests, different abilities, and prominence were different attitudes.

\section{b) Towards ceremonies and upakara}

The ceremony in the terms of time, in this era, has changed the past. In the past, for example, in the case of palebon requiring a lot of time with its complicated ceremony, it has been made easier. The upakara (offerings tool), which completed almost three months, has now been made easier. According to Covarrubias (2015), the Balinese was very free in terms of the religion. It means that Balinese is very receptive to cultures that they thought is suitable for Balinese Hindu religion. According to Kadjeng (1997), based on the holy book, the sacrifice of holy fire is justified, it is not a victim by burning herself in the fire. Likewise, it was explained that the promise of self-was satia or loyalty. There was no mention of sacrificing oneself by burning oneself in the flames in a state of life (Kajeng, 1997: 59).

\section{c) Towards Politics}

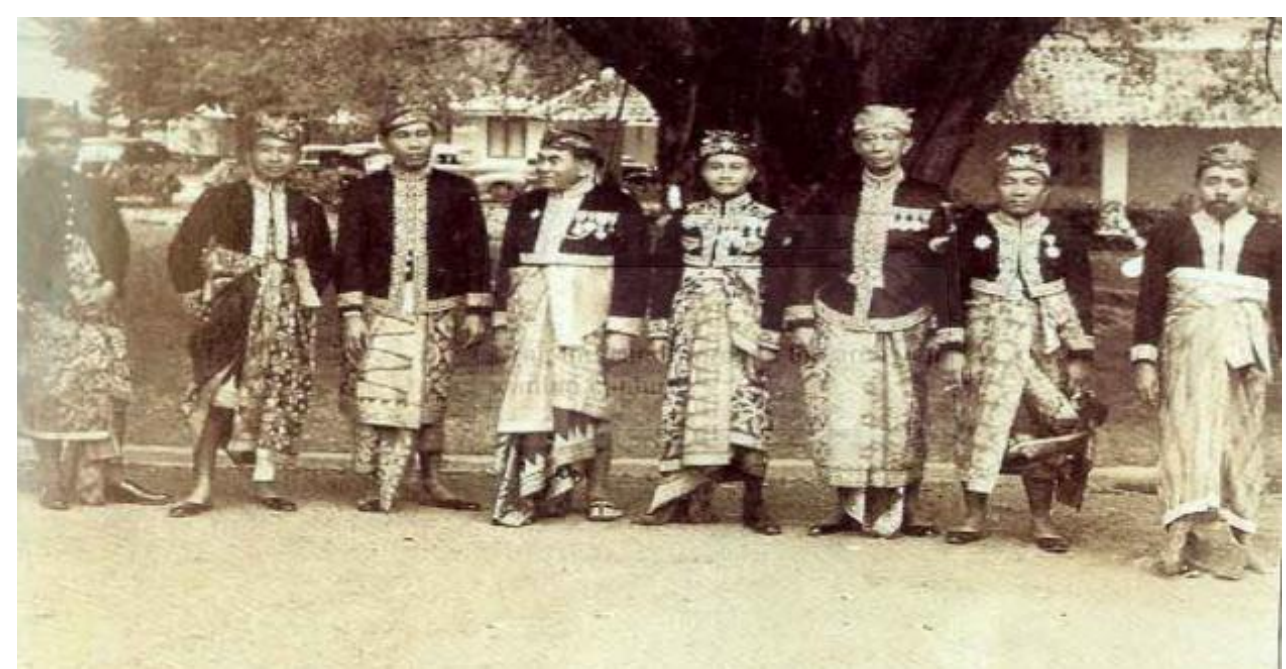

Figure 1. The eight of Balinese Kings in 1938, in front of the Resident's Houses of Bali-Lombok 
The impact on the political was discussed into two i.e., the impact on the political for the king and for the Dutch. Respecting the transformation of the masatia tradition in Gni become masatia rambut. It means that the kings of Bali reduced their political influence. The war with the Balinese kingdoms, all kingdoms can be defeated, thus, a special opportunity for the Dutch to master all fields. The Balinese kings were very disappointed, especially, the kings who fought with weapons. The Balinese kings who initially had full power in the territory of their authority finally had under governed by the Dutch.

\section{d) Towards society}

The kingdom era was very difficult to oppose the king's will. The masatia was a tradition applied by the Balinese kings in the kingdom. There was one factor of the king was worshiped like the god. When the development era experienced, such traditions began to be criticized, especially, in the Dutch era, with the excuse, it did not the good era, and it was abolished. According to Sadwika (1980), stated that exemplified by Guling Wong (unlike sucking piglet but use a human). The event occurred in Tabanan during the reign of King Mekules. The king's envoy when there was balih-balihan (performance for entertaining) in Pura Pakendungan (temple name) found the younger lady sleeping. She was taken and diguling (roasting unlike sucking piglet), her oil was taken and used to treat leprosy suffered by the king and healed immediately. The guling was abandoned in the Pakendungan area, then the trader's group from Pandak came to trade through the coastal route and found it then eaten.

In the end, the spirit of the overthrown lady condemned the merchants to be poor in their area, but if they lived outside will be wealthy (interviewed on August $16^{\text {th }}, 2016$ ). According to the participant, it happened in Tabanan, the mother named Men Darta lend money to a family from Puri Tengah. The money was not returned. In fact, every time the money was requested, it was not given back to Men Darta. Eventually, Gusti Ketut became angry and burned Men Darta to death. That was why there was above story the gate of the castle was Men Darta's genitals that must be passed by the Puri's family (told by I Gusti Putu Samar Gantang, August 16 th , 2016). Thus, the arbitrariness was increasingly selected in the times, such as the example of an incident in Puri Tengah. Regarding the prohibition of the masatia tradition, the public was no longer fear if their daughter marries to the castle, dies of tyranny, and plunges into the flames of life. The community was now related to work in Puri, no longer as it once was, cradling for months in the castle, only as needed. Due to the needs of life currently was very different from the kingdom times.

\section{e) Towards tradition}

The cost surely is high for palebon of the king. Palebon in 2008, according to Gusti Bawa Samar Gantang spent the money IDR, 2,5 billion, countless donations such as rice and coconut from each subak (Balinese irrigation in Bali) in Tabanan about 158 subak (interviewed August 16 ${ }^{\text {th }}, 2016$ ). In the past, unlike Tabanan in 1903, the preparation was very large and complicated. Making terajangan (a big hole) in foursquare, hoard with firewood and make it a high stand as a place to jump, it required a lot of money and energy. Regarding the transformation from masatia to masatia rambut, there was no need to make a hole, enough firewood, and other costs can also be suppressed. All cost was imposed by Puri, sometimes toward the three months later, it needed a lot of money. Therefore, it was not a little castle was sold to finance the tradition. In Buleleng, the impact of the transformation of the masatia tradition, especially in terms of financing, has been reduced or greatly changed. In Payangan, for example, there was no need for a bade (a house for the dead body) to eleven overlaps, just enough to be one bale with one overlap (interviewed to Cokorda Spatika, August 10 ${ }^{\text {th }}, 2016$ ).

\section{f) Towards Hindu views}

Respecting the transformation of the masatia tradition was led by the Dutch since its power began in Bali particularly. It greatly gave an image to the tradition development, especially, the masatia in the future prospects. Indeed, there was turmoil with the kingdoms in Bali firstly, even though the war way with large casualties in the conquest context in Bali. The Karangasem kingdom in east Bali did not protest against the abolition of the masatia tradition. This was proof that the people views for Puri Karangasem have broad or more

Suada, I. N., \& Gelgel, I. P. (2018). Transformation of masatia tradition towards Hindu religion in Bali. International Journal of Social Sciences and Humanities, 2(2), 226-242. https://doi.org/10.29332/ijssh.v2n2.168 
advanced horizons. They realized that the change was natural at the current time. Likewise, the people of the king of Karangasem in Lombok shared the same thoughts in responding to the masatia tradition.

The Buleleng Kingdom for Bali was first powered by the Dutch, also realized that the change was natural in the current time, although there was still a sense of indignation towards the Dutch. Due to Buleleng resistance in $1846,1847,1848$, and the worst was in 1849 many victims fell on the Buleleng party. However, the change was made by the Dutch could be accepted by the Buleleng people generally. Indeed, there was resistance in 1868 erupted in Banjar (West Buleleng), the problem was different. Jembrana was located in West Bali, was also not too challenged of the changes in the masatia tradition which was abolished through the Dutch rules in Bali. Tabanan firstly was very opposed to the Dutch actions in the case of the masatia tradition, even had the masatia was secret. However, it was also finally accepted the change broadly. Unlike, the Badung kingdom was conquered by the power of weapons and the biggest victims in Bali, defending the kingdom, finally grudgingly accepted the Dutch rule, followed by the kingdoms of Tabanan and Bangli. Finally, all the kings in Bali received the Dutch suggestions related to the masatia tradition. The Balinese kings also realized that the long-held traditions needed to be changed because they were no longer in accordance with the current time.

\section{g) Towards current society}

The masatia tradition apparently developed in another form. In term of this was clearly found during regional elections. The winning of Pilkada (the head of regional election) was an example. To enliven the winning the number of supporters showed excitement with magundul.

There has been a shift in magundul meaning if it is compared to masatia rambut at the Pitra Yadnya ceremony in palebon. If the magundul of Pitra Yadnya ceremony is meant to show a grief or give respect, thus, the spirit of the deceased is accepted of the God, whereas, if the Pilkada means celebration way. There was also synonymous with promises, for example, if the candidate wins in the election, the supporters will promise to magundul.

\section{h) Towards on Hindu views}

It was known that in Puputan Badung many people looking for the death by suicide and those shot by the Dutch. Puputan Badung's war took a big victim faced the Dutch in Bali particularly, in Indonesia generally. In the subsequent developments, unlike, when the fighters survived at Puri Kesiman facing of Japan, there were plans to Puputan, but it was thought that what was being faced was not the real enemy, but that Japan had lost to the Allies. Therefore, Puputan's intention was canceled (Pindha, 2004). Puputan Margarana occurred on November $20^{\text {th }}, 1946$, many fighters died. But, the wives of the heroes did not commit satia by suicide or suicide by throwing themselves in the flames. This saw people were increasingly aware of the masatia attitude. According to Wiana (1997), satia can be shown the others way, not having to commit suicide. Related to the example of the working hard to revive the family, was left behind, struggling to continue education for the heroes who had taken part in the war.

\section{Findings}

There were the two findings found in the present study, included:

1) The understanding of the past people (kingdom era) about the masatia tradition was different from the Dutch era and the next era. The masatia was suicide in the past. But, the notion of masatia in the Dutch era did not need to do that behavior. It was very contrary to humanity. Understanding the Dutch era currently remained recognized by Balinese people particularly. It can be proved of the descendants of the king of Bali to transform the tradition into another form which was not contrary to humanity. Of course, the concept of desa, kala, and patra (place, time, and state) determined significantly. In Buleleng, when the Dutch has a power, it was transformed into masatia rambut and currently only in the form of the worship. In Jembrana, due to something and other things, the worship form only and in subsequent developments would carry out with masatia rambut. In Tabanan, it was replaced with masatia rambut, as well as in Klungkung, Karangasem, Mengwi, and in Gianyar, it was known that they worshiped one another among the castle. In Badung, the Pemecutan people using wastra selem (full black colour of Balinese cloth). It was identical to masatia rambut. 
When the king of Bangli died and palebon, the masatia rambut was conducted by the castle family, but lately just worshiped. Thus, it can be stated that the mindset about masatia has undergone a change.

2) Theoretically, the views of Balinese people in addressing the masatia tradition, of course, the time have continued to change since the Dutch era. In order to show the loyalty to the deceased both among the nobility and ordinary people were not always suicidal. Regarding the Dutch era, this change occurred. The views of the people in the castle environment as well as in the community were mostly critical in addressing tradition. The worship itself or with a megundul can represent respect for the soul of the deceased. Thus, the masatia tradition that was glorified in the kingdom era has experienced development and has even emerged with a resignation in the mayor's election, when Rai Wijaya Mantra's partner, Jaya Negara won, a number of supporters supported him. In the gria (the house named for Brahmin caste), like in Gria Buruan Wanasari, the father of Ida Bagus Yuda Triguna in Palebon, he was to show respect to his father with megundul.

\section{Conclusion}

The masatia transformation was occurred in Bali for the 1908-2014 period due to the transition of the colonial rule which in this case was Dutch colonialist. The masatia tradition has been known since 1597 to 1843 and was formally abolished in 1908. The masatia tradition was banned in Bali by the Dutch written agreement with the king of Bali. Although it has been banned, there was only a government to practice masatia in secret until 1920.

The process of transforming the masatia tradition for each castle in Bali takes place slowly. For the Buleleng castles since 1849 might be stated that there was no more masatia, then followed in the kingdom of Jembrana, Badung, Tabanan, Bangli, Karangasem, Gianyar, and finally in Klungkung. When Klungkung collapsed against the Dutch, knocked out of the Klungkung party there were also those who surrendered to the Dutch who later called themselves by the named of Fatimah. This was the only one from Klungkung who can live and finally marry Buleleng people. Puri Jembrana immediately turned to masatia in the form of worship due to the political considerations. In Puri Mengwi since the death of I Gusti Ketut Agung, he had first performed the masatia rambut in 1939. In Puri Tabanan after the fallen of the Tabanan kingdom in 1906, the masatia tradition was gradually replaced and eventually replaced with masatia rambut. Likewise, in the castles of Badung, masatia in the blaze ended in 1906 was eventually replaced with masatia rambut. Then, it was followed at Puri Bangli in 1906, while in Puri Karangasem, the masatia in flames it stopped. The Payangan kingdom had collapsed and was eventually replaced by masatia rambut. Whereas, in Puri Gianyar, the masatia in the blaze of fire had stopped, was replaced with a form of worship only in a little in Gianyar turns.

The process of substituting masatia of the fire occurred the transition process. But, in the end, as a successor was approved by the kings in Bali substituted for masatia rambut. The masatia rambut was used as a substitute due to Hindu community in Bali especially, the hair was considered the most sacred. The hair that was located on the head and as the center was the crown. As a result of the masatia transformation involved the term of tatwa, deeds, ceremonies, and upakara (offering tools). In the terms of stature, people used to die when they died, but their souls would get a heaven, but they, in the end, had the conviction that dying in masatia was wrong. In the scriptures there was nothing.

The impact on morality, good behavior was an attitude that needs to be demanded, everyone. The humans were increasingly critical. In the case of ceremonies and upakara, if in the past most of they did not understand the meaning of the upakara types. They only believe "anak mula keto/indeed like that."

Conflict of interest statement and funding sources

The author declared that he has no competing interest. The study was financed by the author.

Statement of authorship

The author has a responsibility for the conception and design of the study. The author has approved the final article.

Suada, I. N., \& Gelgel, I. P. (2018). Transformation of masatia tradition towards Hindu religion in Bali. International Journal of Social Sciences and Humanities, 2(2), 226-242. https://doi.org/10.29332/ijssh.v2n2.168 
Acknowledgments

The author would like thank the editor of IJSSH for their review, consideration, support, valuable time, as well advice in completed the article. 


\section{References}

1. Ardana, I. G. G. (1982). Sejarah Perkembangan Hinduisme di Bali.

View in (Google Scholar)

2. Ardika, I. W., Parimartha, I. G., \& Wirawan, A. A. B. (2013). Sejarah Bali: dari prasejarah hingga modern. Udayana University Press.

View in (Google Scholar)

3. Arniati, I. A. K. (2018). Young Hindu generation behavior in Denpasar city. International Journal of Linguistics, Literature and Culture (IJLLC), 4(4), 76-85.

View in (Google Scholar)

4. Babad Bali - Bhuwana Winasa. (1840). Gaguritan Buwana Winasa: 16a-16b

View in (Google Scholar)

5. Bhaktivedanta, A. C., \& Prabhupada, S. (1972). Bhagavad-Gita as it is. Bhaktivedanta Book Trust.

View in (Google Scholar)

6. Covarrubias, M. (2015). Island of Bali. Tuttle Publishing.

View in (Google Scholar)

7. Creese, G., \& Wiebe, B. (2012). 'Survival employment': Gender and deskilling among African immigrants in Canada. International Migration, 50(5), 56-76.

View in (Google Scholar)

8. Delgado Wise, R., Márquez Covarrubias, H., \& Puentes, R. (2013). Reframing the debate on migration, development and human rights. Population, space and place, 19(4), 430-443.

View in (Google Scholar)

9. Echols, A. (1984). The taming of the id: Feminist sexual politics, 1968-83. Pleasure and danger: Exploring female sexuality, 50-72.

View in (Google Scholar)

10. Foucault, M. (1977). Discipline and Punish, trans. Alan Sheridan (New York: Vintage, 1979$), 191$. View in (Google Scholar)

11. Foucault, M. (1980). Power/knowledge: Selected interviews and other writings, 1972-1977. Pantheon. View in (Google Scholar)

12. Foucault, M. (1982). The subject and power. Critical inquiry, 8(4), 777-795. View in (Google Scholar)

13. Foucault, M. (1984). Space, knowledge and power. The foucault reader, 239(256). View in (Google Scholar)

14. Foucault, M., \& Deleuze, G. (1977). Intellectuals and power. Language, counter-memory, practice, 205-217. View in (Google Scholar)

15. Geertz, C. (2000). Deep play: Notes on the Balinese cockfight. In Culture and Politics (pp. 175-201). Palgrave Macmillan, New York. View in (Google Scholar)

Suada, I. N., \& Gelgel, I. P. (2018). Transformation of masatia tradition towards Hindu religion in Bali. International Journal of Social Sciences and Humanities, 2(2), 226-242. https://doi.org/10.29332/ijssh.v2n2.168 
16. Gottschalk, L., \& Notosusanto, N. (1975). Mengerti Sejarah: Pengantar Metode Sejarah. Yayasan Penerbit Universitas Indonesia, Jakarta.

View in (Google Scholar)

17. Hendra, S. (2015). Eksplorasi Gending dalam Gamelan Nawa Swara. Kalangwan, 1(2). View in (Google Scholar)

18. Indiani, N. M., \& Suda, I. K. (2018). Interpret Ogoh-ogoh towards Hindu Contemporary Society. International Research Journal of Management, IT and Social Sciences (IRJMIS), 5(1), 65-71.

View in (Google Scholar)

19. Kadjeng, I. N. dkk. 1997. Sarasamuscaya. Surabaya: Paramita.

View in (Google Scholar)

20. KBBI, T. P. (2005). Kamus Besar Bahasa Indonesia. Jakarta: Balai Pustaka. View in (Google Scholar)

21. Koentjaraningrat. (1987). The Javanese of south central Java. Wenner-Gren Foundation for Anthropological Research, Incorporated.

View in (Google Scholar)

22. Korn, B. W. (1969). The Early Jews of New Orleans. American Jewish Historical Society. View in (Google Scholar)

23. Kusuma, I. W., Arung, E. T., Rosamah, E., Purwatiningsih, S., Kuspradini, H., Astuti, J., ... \& Shimizu, K. (2010). Antidermatophyte and antimelanogenesis compound from Eleutherine americana grown in Indonesia. Journal of natural medicines, 64(2), 223-226.

View in (Google Scholar)

24. Martono, N. (2014). Sosiologi Pendidikan Michel Foucault: Pengetahuan, Kekuasaan, Disiplin, Hukuman dan Seksualitas. Jakarta: Rajawali Pers.

View in (Google Scholar)

25. Medera, I. N. (1989). Sarasamuscaya Sebuah Teks Didaktik dan Moralis Jawa Kuna. Denpasar: Pustaka Siddhanta.

View in (Google Scholar)

26. Nordholt, H. G. C. S., \& Putrayadnya, I. B. (2009). The spell of power: sejarah politik Bali, 1650-1940. Pustaka Larasan.

View in (Google Scholar)

27. Nordholt, H. S. (2011). Indonesia in the 1950s: Nation, modernity, and the post-colonial state. Bijdragen tot de taal-, land-en volkenkunde, 167(4), 386-404.

View in (Google Scholar)

28. Pindha, I. G. A. S. (2004). Akne Vulgaris. Dalam: Soetjiningsih, 107-117.

View in (Google Scholar)

29. Poerwadarminta, W. JS 2011. Kamus Umum Bahasa Indonesia.

View in (Google Scholar)

30. Pujileksono, S. (2009). Pengantar antropologi. UMM press.

View in (Google Scholar) 
31. Purbacaraka, P., \& Soekanto, S. (1982). Perihal Kaedah.

View in (Google Scholar)

32. Sadwika, I. N. (1980). Wacana Kritik Sosial dalam Kumpulan Puisi Leak Jagat Karya I Gusti Putu Bawa Samar Gantang. Linguistika: Buletin Ilmiah Program Magister Linguistik Universitas Udayana, 20.

View in (Google Scholar)

33. Salim, A. (2002). Perubahan sosial: sketsa teori dan refleksi metodologi kasus Indonesia. Tiara Wacana Yogya.

View in (Google Scholar)

34. Schulte Nordholt, H. G. (2002). 'A genealogy of violence'.

View in (Google Scholar)

35. Sinom Uwug Payangan. (1982). Babad Bali.

View in (Website)

36. Soekanto, S., \& Brotosusilo, A. (1987). Masyarakat dan kekuasaan. Jakarta: Rajawali Pers.

View in (Google Scholar)

37. Suarda, I. W., Yadnyawati, I. A. G., \& Suda, I. K. (2018). Portrait of Hindu religious teacher performance certified educator in junior high schools Denpasar. International Research Journal of Management, IT and Social Sciences (IRJMIS), 5(3), 53-61.

View in (Google Scholar)

38. Subramanian, A., Tamayo, P., Mootha, V. K., Mukherjee, S., Ebert, B. L., Gillette, M. A., ... \& Mesirov, J. P. (2005). Gene set enrichment analysis: a knowledge-based approach for interpreting genome-wide expression profiles. Proceedings of the National Academy of Sciences, 102(43), 15545-15550.

View in (Google Scholar)

39. Sugriwa, I. G. B. (1978). Penuntun pelajaran kakawin. Sarana Bhakti. View in (Google Scholar)

40. Surat-surat Perdjandjian Antara Kerajaan-Kerajaan Bali/Lombok dengan Pemerintah Hindia Belanda 1841 s/d 1938, 1961, Jakarta : Arsip Nasional.

View in (Google Scholar)

41.Sutrisno, M. (2005). Teks-teks kunci estetika: filsafat seni. Galangpress Group. View in (Google Scholar)

42. Wiana, K. (1997). Cara belajar agama Hindu yang baik. Yayasan Dharma Naradha. View in (Google Scholar)

Suada, I. N., \& Gelgel, I. P. (2018). Transformation of masatia tradition towards Hindu religion in Bali. International Journal of Social Sciences and Humanities, 2(2), 226-242. https://doi.org/10.29332/ijssh.v2n2.168 


\section{Biography of Author}

\begin{tabular}{||l|l|}
\hline & $\begin{array}{l}\text { I Nyoman Suada was born in Peguyangan, November 15th, 1959. He lives at Banjar } \\
\text { Kedua, Peguyangan Kangin Village, Denpasar. He graduated her bachelor degree } \\
\text { (S1) in the Faculty of Letters, Department of Histories, Udayana University, } \\
\text { Denpasar in 1986. He finished his master degree in 2014, at the Magister Program } \\
\text { (S2), Religion, and Culture Sciences at the University of Hindu Indonesia, Denpasar. } \\
\text { He completed his doctoral degree in the Doctor Program (S3), Religion and Culture } \\
\text { Sciences, at the University of Hindu Indonesia in 2018. } \\
\text { Email: nyomansuada07@gmail.com }\end{array}$ \\
\hline
\end{tabular}

